\title{
A GENÉTICA E SEUS CONTEÚDOS ESTRUTURANTES NA INVESTIGAÇÃO DE LIVROS DO PNLD 2015
}

\author{
Cristianni Antunes Leal, Júlio Vianna Barbosa \\ Instituto Oswaldo Cruz \\ Rio de Janeiro, Rio de Janeiro \\ E-mail: caleal1@gmail.com,jub@ioc.fiocruz.br
}

\section{Giselle Rôças}

Instituto Federal de Educação, Ciência e Tecnologia do Rio de Janeiro, câmpus Nilópolis Nilópolis, Rio de Janeiro

E-mail: giselle.rocas@ifrj.edu.br

Resumo: Genética é um conteúdo extenso e importante no currículo escolar e sua compreensão depende do acesso a outros conhecimentos, os quais devem ser previamente adquiridos, tais como: citologia e divisão celular. Entretanto, são dispostos em volumes distintos nas coleções didáticas. Assim, o objetivo deste estudo foi investigar os livros de Biologia do triênio 2015-2017, para mapear como citologia, divisão celular e genética estão apresentadas. Para isso, usou-se o guia de livros didáticos, assumido como corpus documental, sendo escolhidas quatro coleções que chegaram a um colégio público estadual no Rio de Janeiro. Os resultados apontam que os conteúdos necessários para a melhor percepção da genética estão separados em distintas séries escolares, e que o Currículo Mínimo não é seguido por nenhuma editora aprovada no PNLD 2015.

Palavras-chave: biologia, ensino médio, genética, livro didático, Rio de Janeiro.

\section{GENETICS AND ITS CONTENTS ON STRUCTURAL PNLD BOOKS RESEARCH 2015}

\begin{abstract}
Genetics is an extensive and important content in the school curriculum and its understanding depends on access to other knowledge, which must be purchased in advance, such as cytology and cell division. However, they are arranged in different volumes in the teaching collections. The objective of this study was to investigate the biology books for the three years 2015-2017, to map as cytology, cell division and genetics are presented. For this, we used the guide textbooks, taken as documentary corpus, being chosen four collections that reached a state public school in Rio de Janeiro. The results show that the content necessary for better understanding of genetics are separated into different school grades, and the Minimum Curriculum is not followed by any publisher approved in PNLD 2015.
\end{abstract}

Keywords: biology, high school, genetics, textbook, Rio de Janeiro.

Recebido em 03/10/2015. Publicado em 30/09/2016. 


\section{INTRODUÇÃO}

Os geneticistas têm sido impulsionados com as demandas da sociedade, gerando quase que cotidianamente, conhecimentos inovadores cujas temáticas têm sido constantemente inseridas na educação sendo legitimados pela presença desses conteúdos nos livros didáticos (AYUSO e BANET, 2002). Em geral, a ciência da hereditariedade apresentada pela escola é dividida, em pelo menos, três áreas: a genética mendeliana; a genética molecular; e a genética de populações.

A genética mendeliana, também conhecida como genética clássica, foca no estudo de Gregor Mendel, o "pai da genética", apresentando a pesquisa publicada a partir de 1865 e a progressão da genética até a primeira metade do século $X X$, onde foram desenvolvidos seus fundamentos. Normalmente são os primeiros conteúdos apresentados aos estudantes da educação básica. A pesquisa de Thomas Hunt Morgan com a mosca Drosophila comprovaram as leis de Mendel, assim como, expandiu o campo de pesquisa em genética (MAYR, 1998).

A genética molecular surge em torno da década de 1950, tendo como ícone máximo a elucidação da estrutura do ácido desoxirribonucleico (DNA), tendo James Watson, Francis Crick, Maurice Wilkins e Rosalind Franklin como principais personagens. Unindo a ciência da hereditariedade e o DNA como material genético de todas as espécies de seres vivos; sendo inclusive uma forte prova da evolução das espécies (MAYR, 1998).

Já a genética de populações, ou genética da evolução, tem como um dos principais marcos, o Projeto Genoma Humano (PGH). Resultado de um consórcio público e privado que objetivou o sequenciamento dos 3,1 bilhões de bases nitrogenadas do genoma humano (FLÓRIA-SANTOS e NASCIMENTO, 2006). O genoma é o conjunto de DNA de um ser vivo; isso ocorreu em 2003, e o personagem mais marcante é John Craig Venter.

As três áreas se amalgamam entre si e com alguns outros temas da Biologia, considerados como conteúdos estruturantes, sendo eles principalmente: a citologia, a mitose, a meiose, o DNA e o núcleo celular. Logo, a genética e estes conteúdos estruturantes tem um lastro no próprio diálogo com os campos de pesquisa. Entretanto, uma característica da Biologia é a classificação em categorias das áreas de estudos, o que por vezes causa a compartimentação dos conteúdos. No caso da genética essa característica mais atrapalha do que ajuda, já que para compreendê-la são requeridos outros conhecimentos ofertados em distintas séries escolares. No ensino médio, o 
estudo de citologia ocorre no primeiro ano; enquanto o de genética, tradicionalmente, é ensinado no terceiro ano; conferindo um hiato pedagógico e, dificultando, portanto, sua aprendizagem. Trazemos aqui a compreensão de hiato pedagógico proposto por Leal, Rôças e Barbosa (2015), que consideram que tal fato ocorre quando os conteúdos relacionados em algumas disciplinas são ofertados em distintas séries escolares; o que causa uma separação que pode dificultar o progresso do ensino e da aprendizagem.

Considerando que não há uma proposição nacional sobre a ordem com que tais conteúdos devem surgir nos livros, cabe, quase que exclusivamente, as editoras de livros didáticos a decisão de apresentação dos conteúdos por série escolar (NETO e FRACALANZA, 2003). As secretarias estaduais de educação tem buscado alguma organização, porém é pouco comum o diálogo entre os setores. De qualquer forma, foge da competência do professor eleger que assunto é prioritário e/ou mais adequado para uma dada situação no processo de ensino e aprendizagem. O mais próximo que se chegou a essa realidade foram as propostas dos Parâmetros Curriculares Nacionais (BRASIL, 2002), o qual atuou como uma orientação, sem força legal. Na ocasião em que foi divulgado trazia como novidade a interdisciplinaridade, a valorização da cultura regional, entre outras; contudo, o mesmo já tem mais de dez anos desde sua última revisão.

Em 2006, foram lançadas as Orientações Curriculares para o ensino médio, a fim de normatizar o ensino; a de Biologia em um único volume junto com a de Física, a de Matemática e a de Química. Apresentam um olhar mais preocupado com os professores; "sem pretender ser um manual de procedimentos ou protocolos de atividades, o conjunto de orientações a seguir objetiva um diálogo com o professor de Biologia" (BRASIL, 2006, p. 19). Os livros didáticos se inspiraram nos Parâmetros Curriculares Nacionais e nas Orientações Curriculares Nacionais para elaborarem suas coleções. Mas não apenas neles, como segue no próximo parágrafo.

Bonafé e Rodríguez (in SACRISTÁN, 2013), discutem que o currículo do livro didático é pensado para ser reproduzido pelos professores da educação básica. Entendem que a escola atua como palco para uniformizar e homogeneizar as práticas e o pensamento do grupo hegemônico. De acordo com os autores "o livro didático é o artefato que dá forma material a um modo de proceder pedagógico para a reprodução cultural. O currículo se torna texto e sua materialização coloniza a vida na aula" (p. 209). 
Apesar das questões apresentadas até o momento sobre os livros didáticos, é importante destacar que anteriormente ao Programa Nacional do Livro Didático (PNLD), instituído no ano de 1985, pelo Decreto no 91.542, não havia qualquer tipo de avaliações das coleções. Atualmente o PNLDEM (para o ensino médio) abrange todas as disciplinas, sendo os livros didáticos desse segmento avaliados por professores universitários, igualmente como por professores da educação básica. Assim, busca-se minimizar ou excluir erros que outrora existiam nas coleções, de acordo com o portal do Fundo Nacional de Desenvolvimento da Educação ${ }^{1}$. Caimi (2015) discute a cartografia dos avaliadores e das editoras dos livros didáticos, identificando que há pouca diversidade entre as coleções para contemplar a heterogeneidade cultural do Brasil, mas que apesar dessa característica, conseguem êxito na aprovação de suas coleções, provavelmente por serem grandes editoras.

No que tange as coleções de Biologia do triênio 2015-2017 os professores que avaliaram os livros são de várias regiões do Brasil, atuando em várias esferas do ensino para congregar cenários e visões diferenciadas para o ensino em Biologia. Os livros são avaliados às cegas e temas específicos, como citologia e genética foram primeiramente observados por professores especialistas. A política da aprovação das coleções consideraram critérios estabelecidos pelo Ministério da Educação.

A análise das coleções aprovadas para o triênio em questão abrangeu uma área ampla, contemplando todas as disciplinas, portanto, com critérios comuns e, outros eliminatórios específicos às áreas de Ciência da Natureza. Restringindo-se apenas à Biologia, há ainda dois outros critérios: a orientação para abordagem do componente curricular Biologia e o manual para os professores da educação básica. Logo, cada coleção aprovada passou por quatro critérios de análise.

O livro didático apresenta-se como mediador cultural e pedagógico que pode auxiliar para que a biologia seja trabalhada pedagogicamente de modo que as discussões dessas temáticas contemporâneas estejam presentes nos currículos das escolas brasileiras (BRASIL, 2014, p. 22).

\footnotetext{
${ }^{1}$ Disponível em: <http://www.fnde.gov.br/programas/livro-didatico/livro-didatico-historico>. Acesso em: 27 de set. de 2015.
} 
Particularmente, no Estado do Rio de Janeiro, a partir de 2012, a Secretaria Estadual de Educação do Rio de Janeiro (SEEDUC-RJ) lançou o Currículo Mínimo para Ciências e Biologia, tal currículo parte da premissa que todas as escolas públicas estaduais precisam cumprir o currículo, há penalizações para as que não cumprem. Para isso, ocorreu mudanças na legislação estadual como a promulgação da Resolução SEEDUC no 4.866 de 14 de fevereiro de 2013 que implementa este currículo como obrigatório nas escolas da rede SEEDUC-RJ (RIO DE JANEIRO, 2013). O Currículo Mínimo é considerado uma referência para todas as unidades de ensino da rede estadual e "sua finalidade é orientar, de forma clara e objetiva, os itens que não podem faltar no processo de ensino-aprendizagem, em cada disciplina, ano de escolaridade e bimestre" (RIO DE JANEIRO, 2012, p. 02). Ao analisar o Currículo Mínimo, o mesmo apresenta citologia e genética no mesmo ano de escolaridade: o primeiro ano do ensino médio. Compreende-se que se trata primeiramente da genética mendeliana. É uma mudança importante no currículo, logo, investir na formação continuada faz-se necessária para que os professores se sintam confortáveis em problematizar e ressignificar a temática que aborda vários saberes sem ficarem reféns do que é proposto pelo Currículo Mínimo.

Tal currículo sinaliza que a triangulação entre citologia, divisão celular e genética mendeliana é especialmente relevante para a educação biológica na rede SEEDUC-RJ, embora haja imprecisões no que é esperado, pois no trabalho de Leal, Rôças e Barbosa (2014) encontrou-se que os estudantes do terceiro ano do ensino médio ainda não percebiam a genética.

Assim, o pressuposto deste estudo é que os conteúdos estejam entrelaçados e contextualizados para estudantes da educação básica a fim de alcançar uma melhor compreensão sobre a temática; e a pergunta deste estudo é: como estão os conteúdos estruturantes e a genética escolar nos livros do PNLD 2015-2017? Desse modo, o objetivo dessa pesquisa foi investigar os livros didáticos de Biologia do triênio 2015-2017, para conhecer como lidam com a genética e seus conteúdos estruturantes. Para isso, usou-se o guia de livros didáticos e quatro coleções que chegaram a um colégio público estadual no Rio de Janeiro.

As atividades devem ir mais além, explorando a criatividade e novas habilidades, possibilitando que a democratização digital diminua também distanciamentos sociais (MORAN, 1997), porque muitos dos jovens que passam pela escola pública, não têm oportunidade de contato com 
orientações e uso de computadores e suas possibilidades são menores ainda em espaços fora da escola.

\section{PERCURSO METODOLÓGICO}

O Ministério da Educação lançou um guia com as coleções aprovadas e suas principais características, junto com orientações sobre como abordar os assuntos (BRASIL, 2014). Nove coleções foram aprovadas (Anexo 1), e os livros do ensino médio chegaram para escolha dos professores no ano de 2014 para iniciarem o triênio em 2015. Os critérios da ficha para avaliação são pontuados no quadro 1 abaixo.

Quadro 1. Critérios avaliados das coleções de livros de Biologia.

\begin{tabular}{|l|l|}
\hline \multicolumn{1}{|c|}{ Conteúdos analisados nas fichas avaliativas } & № de itens avaliados \\
\hline a) Descrição da coleção/obra impressa & 02 \\
\hline b) Descrição da coleção/obra digital & 02 \\
\hline $\begin{array}{l}\text { c) Respeito à legislação, às diretrizes e às normas oficiais } \\
\text { relativas ao ensino médio }\end{array}$ & 08 \\
\hline d) Coerência e adequação metodológica & 09 \\
\hline e) Correção dos conceitos, informações e procedimentos & 13 \\
\hline f) Construção da cidadania e convívio social republicano & 05 \\
\hline g) Manual do professor & 16 \\
\hline h) Atividades & 04 \\
\hline i) Imagens e ilustrações & 07 \\
\hline j) Projeto gráfico-editorial & 08 \\
\hline k) Objetos educacionais digitais - OEDs & 10 \\
\hline
\end{tabular}

Fonte: Dados da pesquisa.

As novidades neste triênio nos livros de Biologia foram inserções de questões como a "biodiversidade, as relações de gênero, as sexualidades, os corpos, as relações étnico-raciais, os direitos humanos e as culturas" (BRASIL, 2014, p. 22) em acordo com o ensino de Biologia. Portanto, são obras mais similares entre si do que distintas em seu conjunto, conforme preconizado no texto do guia: 
Leal, Rôças, Barbosa, 2016 - Tecnologias Educacionais

Um professor que utilize o livro didático em suas aulas conta com uma sequência já organizada de apresentação dos assuntos. Diante da proposta dos temas estruturadores, e considerando a sua realidade específica, as necessidades de seus alunos, as particularidades de sua escola e região, o professor pode selecionar os temas que são mais significativos e resolver como deverão ser trabalhados de modo a possibilitar situações de aprendizagem a partir das vivências dos alunos (BRASIL, 2006, p. 22).

Para evitar que as coleções entrem em conflito com o que é assumido como politicamente correto, o livro didático também se redirecionou para estes fins, assumindo discursos da teoria queer, renegando a discriminação étnica ou racial, assim como evitando ilustrações estereotipadas e descontextualizadas (SACRISTÁN, 2013).

Quatro coleções chegaram a um colégio público da Baixada Fluminense, no Rio de Janeiro que pertence a SEEDUC-RJ e, por esse motivo, são os investigados neste estudo, quanto ao quesito genética e seus conteúdos estruturantes. Suas identificações seguem no anexo 2.

Desta forma, o percurso metodológico desse estudo foi conhecer o guia de livros didáticos, assumido como corpus de análise desse estudo, em conjunto com as quatro coleções que chegaram ao colégio; com a finalidade de investigar como são apresentados os conteúdos estruturantes e a genética. A coleta de dados deu-se por meio da análise de textos do guia e dos quatro livros que chegaram ao colégio.

O colégio em questão não é considerado de difícil acesso para justificar a ausência das demais coleções. A coleção que chegou como escolha da equipe docente desse colégio foi a "Ser Protagonista". O triênio encerra no final do ano letivo de 2017; e, de acordo com o portal institucional da SEEDUC-RJ, em 2014 foram realizadas 431.172 matrículas no ensino médio nesta rede. O livro didático chegou para todos os estudantes da SEEDUC-RJ gratuitamente no ano letivo de 2015, e quando isto não ocorreu, novos livros foram pedidos. A investigação das coleções foi realizada considerando a triangulação entre a citologia, a divisão celular e a genética.

As quatro coleções foram investigadas primeiramente pelo sumário e posteriormente, pelos conteúdos abordados e, pesquisados se os mesmos estão em concordância com o Currículo 
Leal, Rôças, Barbosa, 2016 - Tecnologias Educacionais

Mínimo usado nas escolas da SEEDUC-RJ e com o desejado pela literatura de ensino de genética em unir citologia, divisão celular e genética em uma mesma série escolar.

\section{A ANÁLISE E APRESENTAÇÃO DOS LIVROS}

No quadro 1 chama a atenção o "manual do professor" com dezesseis quesitos para ser analisado pela equipe responsável; se destaca por se o item que apresenta o maior número a ser explorado e respondido. Isto sugere que o professor da educação básica ainda é visto como executor do currículo, por isso que tem que ser tão detalhista o manual do livro didático, para que o docente tenha menos trabalho ao usar o livro, além de já existir o plano de aula pronto, e, de ser por ele que os professores da educação básica podem se guiar para escolher as coleções aprovadas. No livro didático este "manual do professor" é interpretado como a materialidade da forma de ensino e aprendizagem no padrão de ordenação dos conteúdos, entendido, em muitas vezes como único (MOREIRA e MARTINS, 2015a).

O mercado de livros didáticos e o próprio Ministério da Educação reconhecem e legitimam isto quando valorizam o manual. Provavelmente os professores da educação básica nem percebam tal situação, inibindo iniciativas destes professores em elaborar práticas alternativas aos livros didáticos. O dilema do professor vai além, pois apesar de reconhecer que há outras formas de ensinar os conteúdos, ele necessita explicar o motivo pelo qual não cumpre o plano do livro didático, justificando suas escolhas junto aos responsáveis dos estudantes e a equipe pedagógica pelos conteúdos selecionados. A pressão pelo cumprimento dos conteúdos que estão padronizados nas coleções é forte. Portanto, é uma doutrinação, sendo um retrocesso diante das conquistas na pesquisa científica e no campo educacional.

De acordo com Moreira e Martins (2015b) os textos do livro didático são vistos como tecnologias, já que são aparatos materiais com vistas a atingir uma finalidade social específica por meio da prática educativa, sendo tecnologias discursivas importantes e fontes de linguagem científica escrita para a maioria dos estudantes. Os textos didáticos significam e produzem efeitos potenciais nos sujeitos.

A importância em discutir o livro didático atualmente está no papel que este também assume, e é imbuído desse papel que apresentamos os quatro livros selecionados para esse estudo, quando consideramos a fala de Caimi ao assumir os livros didáticos 
Leal, Rôças, Barbosa, 2016 - Tecnologias Educacionais

Como suporte cultural que mobiliza inúmeros atores sociais na sua produção, circulação e consumo, tais como: gestores educacionais, pesquisadores, professores, estudantes e suas famílias, políticas educacionais públicas, mercado editorial, mídia, enfim, o conjunto da sociedade brasileira.

$[\ldots]$

O livro oferece uma visão panorâmica do conhecimento acumulado pela humanidade, garantindo o acesso a um passado comum e a uma herança que precisa ser compartilhada por todos (CAIMI, 2015, p. 526).

Dessa forma, após a análise das nove coleções por meio do guia, reconhece que citologia é um tema extenso e em todas as coleções é apresentada no primeiro volume, enquanto que genética, em apenas uma coleção é apresentada no segundo livro (no 01). Seja como for, demonstra uma separação dos temas e as séries escolares do ensino médio, em todas as coleções.

A citologia e a divisão celular são apresentadas no primeiro ano do ensino médio, tendo uma lacuna no segundo ano, e genética no terceiro ano, o que é mais uma justificativa para o motivo pelo qual o ensino de genética tem apresentado entraves. Para Bonafé e Rodríguez (in SACRISTÁN, 2013) "não existe uma variedade real de possibilidades de desenvolvimento curricular. Praticamente todos os livros ensinam o mesmo da mesma maneira" (p. 214). Ainda que com uma oferta de campo editorial plural, os conteúdos são os mesmos, mostrando uma homogeneidade formal absoluta na estrutura de tarefas. Com Moreira e Martins (2015a), é apresentado que os livros didáticos apresentam ainda roteiros tradicionais de ensino e apresentando sequências lineares e fragmentadas no conteúdo, apesar de todo um investimento crescente em pesquisas científicas e acadêmicas.

O PNLD oferece o livro didático de Biologia a todo estudante da rede pública da educação básica. O livro didático ainda é o principal recurso de instrução, denota, portanto, que os professores tem uma vinculação com as coleções, mesmo estando defasadas diante de uma área de conhecimento com descobrimentos quase que diários, como é o caso da genética, talvez por isso ainda haja uma valorização da genética mendeliana diante das demais (AYUSO e BANET, 2002; SACRISTÁN, 2013; MOREIRA e MARTINS, 2015a). 
De acordo com Greenwood e Fonseca (2016), o livro didático é uma ferramenta valorosa para o ensino e aprendizagem, além de ocorrer uma ressignificação em seu uso pelos professores, já que os mesmos não o seguem fielmente, mesmo assim o livro "continua sendo importante objeto de consulta e apoio para o planejamento do professor, e, por vezes, a única fonte de leitura para informação e conhecimento disponível ao estudante e sua família" (p. 203).

Acerca da investigação geral das obras, a mesma já foi realizada e sumarizada no guia (BRASIL, 2014), o que se pretende a partir de agora é o seu redirecionamento aos pontos específicos do estudo: a genética e seus conteúdos estruturadores. Deste modo, as obras são investigadas sob o ponto de vista da compreensão da hereditariedade. Segue a descrição de cada coleção que chegou a um colégio público estadual no Rio de Janeiro.

\subsection{Coleção "Bio"}

O texto dialoga com os leitores, chamando-os para reflexões acerca do pensamento biológico. Os conteúdos são apresentados de forma gradual e interligados, e, a célula é a unidade básica da vida. Doenças humanas são mencionadas, talvez como estratégia para chamar a atenção dos leitores.

Os ácidos nucleicos aparecem no volume 01 com estrutura e função. Sob o aspecto da hereditariedade, os genes são mencionados como segmentos da molécula do DNA e responsáveis pelas características dos indivíduos; mas sem entrar em detalhes.

Também no livro 01, a citologia é primeiramente abordada com a história da ciência, o desenvolvimento tecnológico e a teoria celular. Após uma visão geral são abordados os conteúdos de membrana plasmática, citoplasma, divisões celulares e núcleo celular. Existem figuras reais e esquemas; o citoplasma é analisado sob o ponto de vista funcional e morfológico e, as células eucarióticas são mais exploradas que o modelo procariótico.

Nas células eucarióticas, o núcleo é reconhecido como o detentor do material genético, o DNA. Os nomes específicos (cromatina, cromossomos, heterocromatina, eucromatina, cromátide) são mencionados ao longo do texto junto com seus significados, porém, são muitas definições em um único texto, com palavras muito parecidas, mas distintas definições. Neste momento, o núcleo é abordado junto com a divisão celular. 
As fases da meiose são demonstradas, mas seu papel na variabilidade genética não é destacado neste volume. A meiose analisada é a gamética que é a que ocorre em animais. A origem dos nomes não é retratada e, prevalece os desenhos e esquemas para cada fase.

A novidade curricular desta coleção é que é a única, dentre as nove aprovadas, que apresenta genética no segundo volume, logo, é para ser utilizado na segunda série do ensino médio. Neste volume são três unidades, e a genética compõe a segunda unidade.

No volume 02 , os conteúdos estruturadores são convocados ao debate, com a citologia, e o DNA, porém, a meiose, não é resgatada no primeiro capítulo que aborda genética. A apresentação é feita justificando a importância em se estudar a hereditariedade, para posterior estudo da história desta ciência. Considerando as divisões da genética, a primeira a ser estudada é a molecular, percebe-se isto pelo estudo do DNA e sua importância para tal ciência, inclusive com sua função semiconservativa e a síntese proteica. Tenta-se integrar os conhecimentos por meio de exercícios e estes com as habilidades requeridas pelo Exame Nacional do Ensino Médio (ENEM).

No capítulo seguinte, a genética mendeliana é apresentada, a meiose é relacionada com a primeira lei de Mendel e os termos comuns a esta área são usados com seus significados, sendo eles: dominante, recessivo, híbrida, homozigótica, heterozigótica, fenótipo, genótipo, entre outros. Também é problematizada a simbologia utilizada para representar os alelos, como o " $A$ " e "a".

Há uma valorização nas leis de Mendel, com implicações no dia a dia, e com exemplificações nos humanos. Há vários esquemas em conjunto com o texto explicativo. Noções de probabilidade são explicadas para posteriores cruzamentos com as leis de Mendel. O que foge destas leis, também é abordado, como a dominância incompleta, a codominância e a penetrância.

Em outro capítulo, a segunda lei é estudada com a teoria das probabilidades. Não fica restrito a esta lei, já que aborda suas exceções, até chegar à terceira divisão da genética, o Projeto Genoma Humano.

Em cinco capítulos a genética é apresentada relacionando-se aos conteúdos necessários. Para isto os autores usam muitas figuras, quadros e exemplificações humanas. Para exercitar os 
conhecimentos, exercícios do ENEM, de universidades e elaborados pelos autores são apresentados.

Na seção do "manual do professor", há apresentações de centros de divulgação da ciência no Brasil, orientações para avaliar os estudantes, o que deve ser considerado. Há uma preocupação com as competências requeridas pelo ENEM. Para a genética há sugestões de filmes e de como abordar a temática. Quanto aos conteúdos, são muitos e vem na intenção de ampliar os mesmos. Existe uma preocupação em integrar os conteúdos.

Logo, nesta coleção, o ensino de genética se justifica por sua importância na saúde e tecnologia e, com a inclusão da biotecnologia por meio da engenharia genética e seus benefícios em usá-la. Valorizam-se os exercícios, mas quase não há experimentação para os estudantes realizarem.

Esta coleção aborda genética no seu segundo volume, porém segue a mesma estrutura das outras coleções, ou seja, os conteúdos, normalmente abordados no ensino médio são todos contemplados mesmo que em ordem (volumes) diferentes.

\subsection{Coleção "Biologia hoje"}

A coleção produz uma visão geral da Biologia como tentativa de contextualizar seu estudo, inclusive já sinaliza a hereditariedade por meio de uma figura em qual é explicada como são herdadas as características de um organismo.

O volume 01 apresenta as divisões da Biologia: citologia, histologia, anatomia, embriologia, genética, evolução, ecologia, taxonomia, paleontologia, zoologia, botânica e microbiologia. Deste modo, percebe o objeto de estudo na coleção: a citologia e a genética.

A citologia é primeiramente abordada integrando a curiosidade e a necessidade de estudá-la para compreender melhor a origem das doenças e assim, contribuir para novidades em medicamentos e tecnologia. Logo, o texto justifica a importância antrópica em estudar citologia.

É abordada a história da citologia em conjunto com o desenvolvimento tecnológico que permitiu estudar a célula e suas estruturas. A teoria celular é rapidamente citada e os modelos celulares (célula procariótica, célula eucariótica animal e vegetal) são igualmente mencionados, usando esquemas para apontar similaridades e diferenças entre elas. Valoriza-se a célula eucariótica. 
O estudo da membrana plasmática é realizado em um capítulo, assim como o citoplasma da mesma forma. No capítulo do citoplasma há as organelas com suas formas e funções. O núcleo aparece na unidade seguinte por meio de suas funções para o funcionamento da célula.

O núcleo é abordado junto com os cromossomos e um conjunto de novos nomes (cariolinfa, envelope nuclear, nucléolos, nucleoplasma, alossomos, nucleossomo, entre outros) são apresentados. São muitas definições em um capítulo.

O estudo dos ácidos nucleicos ocorre em um capítulo e a hereditariedade é revelada por meio das mutações. Em seguida, o capítulo do tema divisão celular aparece. Primeiramente mitose e suas fases. A meiose é apresentada como uma função da reprodução sexual; e a variedade genética é mencionada neste volume, mas sem entrar em detalhes. As alterações cromossômicas e a gametogênese são estudadas dando a oportunidade para o professor apresentar a genética já no primeiro ano.

No volume 02 , os conteúdos estudados são os seres vivos, e embora, o modo de reprodução seja contemplado, não há a preocupação com a hereditariedade, pois isto foi realizado em outros volumes da coleção.

O volume 03 da coleção contempla a genética. Os autores iniciam afirmando que genética estuda as leis da hereditariedade, mas sob a perspectiva de "lei" embute a ideia de ser uma verdade universal, que os estudos subsequentes da pesquisa de Mendel afirmaram haver exceções. Isto é revisto de forma relativa conforme os capítulos são estudados, ao se abordar as restrições das leis de Mendel.

A genética mendeliana é a primeira apresentada ao se abordar às pesquisas com as ervilhas de Gregor Johann Mendel, sendo que a primeira e a segunda lei de Mendel são estudadas em capítulos distintos, junto com as regras de probabilidade e exercícios resolvidos são demonstrados. O conteúdo de meiose é necessário e, os autores do livro didático citam o volume 01 para rememorar o conteúdo. Esquemas simplificados foram feitos para chamar atenção para as etapas mais importantes com os cromossomos e a hereditariedade. 
Na segunda unidade, é explorada a genética após Mendel, caracterizando a genética molecular com suas aplicações, assim como, a de populações. Doenças e curiosidades da genética humana são exploradas.

Há simulações e atividades práticas, como a extração de DNA de morangos viáveis de ocorrer em uma escola. Os exercícios são de elaborações dos autores, do ENEM e de vestibulares.

No "manual do professor", há orientações para a melhor exploração dos livros, com os objetivos gerais da coleção, os Parâmetros Curriculares Nacionais são mencionados, demonstrando com isso estar em sintonia com o que é estipulado a nível nacional. Há também a menção da tendência pedagógica construtivismo para a abordagem pedagógica. Os critérios de avaliações também são explorados, mas com o cuidado de não ser somativa ou classificatória e, sim, contínua e formativa.

Recursos adicionais, atividades interdisciplinares, e materiais didáticos digitais também são contemplados para orientar o professor em seus usos e, como podem colaborar para a aprendizagem.

É uma coleção com muitos detalhes e preocupada em contextualizar os conteúdos, mas recaindo em uma visão antrópica para, talvez, agradar os estudantes.

\subsection{Coleção “Conexões com a Biologia"}

Esta coleção convida os leitores com textos em que compartilham questões e convoca a reflexões, o que torna um texto agradável para os jovens.

No volume 01, a novidade anteriormente citada, aparece com debates sobre biodiversidade, relações de gênero, sexualidades, corpos, relações étnico-raciais. Estas são contempladas logo no início do primeiro volume, com o nome de "as transformações do ser humano". Discutem as fases da vida humana e o sistema genital, temas que por si só já despertam o interesse dos jovens. A segunda unidade é a Biologia como ciência e seu desenvolvimento no campo.

As subáreas da Biologia são apresentadas, sendo elas: ecologia, zoologia, paleontologia, evolução, genética, microbiologia, embriologia, citologia, virologia, anatomia, fisiologia, botânica e bioquímica. 
Há a composição dos ácidos nucleicos com a abordagem genética quando afirma que eles estão relacionados, também, a transmissão da informação genética, mas sem entrar em detalhes como isso ocorre.

A unidade quatro inicia o estudo da célula com uma questão envolvendo uma doença e com o mapa mundial, tenta, portanto, relacionar a doença com a célula contextualizando-a. Inicia a citologia primeiramente com a descoberta da célula, é realizada em conjunto com o desenvolvimento tecnológico e a teoria celular. Trabalha-se com a diversidade celular e suas quatro características básicas comuns: membrana plasmática, material genético, ribossomos e citosol. Os modelos procariótico e eucariótico também são abordados. Em seguida, há os capítulos de membrana plasmática, citoplasma e organelas, núcleo celular e, o núcleo e divisão celular.

No capítulo de núcleo e divisão celular, o DNA é convocado, com seu papel semiconservativo, na e para a genética. Conteúdos que seriam da genética, já neste capítulo são mencionados, como os cromossomos, cromatina, nucleossomo, haploide, diploide, para depois apresentar em outro capítulo o ciclo celular e mitose e posteriormente, meiose com a variabilidade genética e suas fases.

O volume 01 , portanto, permite a abrangência até genética ao citá-la em vários exemplos e em alguns exercícios, porém sem nomear a área.

No volume 03, a genética é apresentada, primeiramente a história do desenvolvimento desta área para posterior estudo. Já em capítulos distintos surge a primeira e, depois, a segunda lei de Mendel. Em todos estes capítulos há figuras e esquemas para os cruzamentos mendelianos.

No quarto capítulo, "bases físicas da hereditariedade", a teoria cromossômica é requisitada, junto com vários nomes exclusivos da genética, como: genótipo, fenótipo, homozigoto, heterozigoto, alelos dominantes, alelos recessivos, genes e heredogramas.

A probabilidade também é contemplada no ensino de genética, assim como outros tipos de herança (dominância incompleta, codominância, alelos múltiplos, herança ligada ao cromossomo Y, herança mitocondrial, herança poligênica ou quantitativa). Há uma preocupação em esclarecer a miscigenação do povo brasileiro, como resultados de cruzamentos. 
A genética molecular aparece na unidade dois com suas aplicações, logo, passa-se uma ideia de que o desenvolvimento desta área ajuda a humanidade. Neste momento o conceito de código genético e a estrutura do DNA são resgatados. A expressão gênica igualmente é apresentada. As mutações, a engenharia genética e as eras genômica e pós-genômica são igualmente expostas. Percebe-se uma visão antropocêntrica nestes capítulos. Tendo como ponto de partida sempre a humanidade, ao se reduzir ao homem.

A coleção apresenta muitos quadros, esquemas e figuras para sintetizar os conteúdos; como em outras coleções, há muitas definições. Os conteúdos estruturantes da genética são separados no volume 01 e genética no volume 03, assim, há um claro hiato pedagógico para os estudantes do segundo ano do ensino médio. Embora esta coleção tenha o cuidado de contextualizar os conteúdos e desta forma, rememorar o que já foi estudado. Mesmo com este esforço, um ano separa os conteúdos. Já acerca dos exercícios, são pouquíssimos identificados como de universidades, prevalecendo, então, os exercícios de elaboração da autora.

Na seção "manual do professor", se justifica em porque ter feito à divisão dos conteúdos nos três volumes, usando as políticas públicas para o ensino médio. Há a orientação para avaliar os estudantes. Uma preocupação com as habilidades e competências é percebida quando entra nas orientações específicas de cada unidade. Atividades práticas, simulações também são objetos de estudo da autora e a mesma apresenta para os docentes realizarem. Há recursos complementares usando a internet, livros e filmes. Mesmo nesta seção ainda prevalece esquemas e quadros.

Deste modo, citologia, DNA e divisão celular estão presentes no volume 01, e genética no volume 03. Mesmo trazendo a novidade da inserção de relações de gênero, entre outras, ainda prevalece os pré-requisitos para compreender genética em volumes separados.

\subsection{Coleção "Ser Protagonista"}

É uma coleção com a abordagem clássica dos livros de Biologia. Da mesma forma que as demais coleções, há um esforço para contextualizar o ensino de Biologia.

No volume 01, o capítulo inicia explicando o que é a Biologia e seus objetos de estudo. Apresenta também as áreas frequentemente abordadas, sendo elas: citologia ou biologia celular, histologia, anatomia, embriologia, botânica, zoologia, fisiologia, genética, evolução, ecologia e sistemática. 
Os capítulos iniciam os temas em forma de unidade para depois unir as áreas de conhecimento, trata-se, portanto, de uma tentativa de crescimento gradual de informação, do mais simples ao mais complexo. A molécula do DNA é reconhecida na transmissão durante a reprodução dos seres vivos, carregando informações para a produção de proteínas. O DNA é estudado em sua forma e função, mas sem se preocupar em explicar a hereditariedade.

A célula aparece no surgimento da vida e a teoria endossimbiótica tem destaque neste volume. A unidade dois do volume 01 apresenta a citologia com estrutura e função das células, nesta unidade há o núcleo celular e a divisão celular como pré-requisitos para o estudo da genética. Em quadros, há a presença da história de algum tema, mostrando o desenvolvimento científico e tecnológico. A cada assunto estudado, ao final existem exercícios sobre o tema.

Na composição do núcleo, nomenclaturas surgem, sendo elas: carioteca, nucleoplasma, cromatina, nucléolo, poros, entre outros. Os cromossomos são abordados, inclusive com o cariótipo humano. Há uma ênfase nos cromossomos homólogos e na reprodução sexuada da espécie humana. A divisão celular, com a mitose e a meiose são detalhadamente apresentadas com muitas figuras e quadros.

O DNA é reapresentado na próxima unidade com seu papel de duplicação semiconservativa, reconhece o gene como um segmento de DNA capaz de gerar uma molécula de RNA, que pode, ou não, resultar na produção de um polipeptídio, mas, ressalta a discussão em torno da definição de gene. O genoma humano é considerado um conjunto completo de genes contidos em todos os cromossomos de um indivíduo e também ressalta a discussão em torno do gene como unidade responsável pela hereditariedade, proposto pelo modelo da genética clássica. No final deste capítulo, há um protocolo para extração de DNA.

No volume 02 são abordados: os vírus, os reinos dos seres vivos e as fisiologias, sem se preocupar em coadunar os diversos conteúdos de Biologia.

O volume 03 já inicia o livro com a genética e sua progressão histórica, relaciona rapidamente a meiose e aos gametas, assim como o papel dos cromossomos na hereditariedade, também há a relação do DNA com o cromossomo e a estrutura do DNA. Percebe-se que tenta resgatar os conceitos do volume 01 . 
No capítulo dois, os trabalhos de Gregor Mendel ganham espaço, logo, a genética se inicia com a versão clássica. Noções de probabilidades são apresentadas com exemplos de questões. A primeira lei de Mendel é apresentada, após, há as exceções a esta lei.

A segunda lei de Mendel surge no capítulo cinco, com a teoria intercalada com figuras, quadros e esquemas assumindo o papel de sintetizar os conteúdos. Ao final do capítulo, há exercícios explorando as ideias anteriormente mencionadas.

No capítulo seis, o tema é "além da genética mendeliana" se preocupando em não focar apenas em uma classificação da genética. Biotecnologia também é alvo de estudos no capítulo oito, principalmente em sua utilização para a espécie humana, o que entra em acordo com o Currículo Mínimo.

Na seção de "manual do professor" a coleção é apresentada para o docente melhorar os conteúdos, com preocupação com as competências e a interdisciplinaridade. Há orientações para que o professor faça as atividades práticas, com orientações do que fazer em saídas a campo. Para cada volume há orientações didáticas para cada conteúdo com sugestões de livros, filmes e sites para o professor usar em suas aulas. No final do manual há uma relação de espaços, separados por regiões, para serem visitados.

Entende que esta coleção é mais tradicional, sempre com muitos conteúdos, ao final de cada capítulo muitos exercícios. Sintetiza por meio de figuras e esquemas, apresenta atividades práticas e simulação. Os exercícios são compilados entre vestibulares, ENEM e elaborados pela autora.

\section{COSTURANDO AS ANÁLISES}

Após a investigação das quatro coleções, é possível afirmar que as mesmas apresentam mais similaridades entre si, do que diferenças. Embora haja uma forma diferente e até mesmo, em volumes distintos, os conteúdos apresentados são os mesmos. Na terceira coleção examinada, é possível perceber, claramente, as discussões de gêneros, em outras, está de forma mais tímida. Todos os autores apresentam suas coleções e explicam cada seção que se repete nos demais volumes, presumindo que isto melhora o ensino da Biologia. A seção "manual do professor" apresenta várias formas de executar o planejamento para o ensino de Biologia, ora mais incisivo, ora menos, mas nenhuma foge de instruir o professor para melhor aproveitar o livro didático, 
inclusive, com dicas sobre avaliação dos estudantes. Logo, as reflexões do professor, as criações de alternativas metodológicas e didáticas, acabam sendo inibidas diante das opções legitimadas no manual e aprovadas pelo Ministério da Educação.

As quatro coleções pertencem a editoras de São Paulo. Este estado está em um contexto que foge das demais unidades federativas, incentivar outras editoras que valorizam as diversas regiões do Brasil, também possa de fato, refletir o regionalismo esperado, mesmo que tenham sido avaliados por professores de diversas regiões. Há uma clara ausência da heterogeneidade entre as editoras e entre os autores e/ou editores de livros didáticos e isto, influencia nas aulas, pois "o livro texto continua sendo a principal referência na estrutura e no desenvolvimento da atividade docente" (BONAFÉ e RODRÍGUEZ in SACRISTÁN, 2013, p. 219). o estudante que o usa, precisa se ver naquele universo apresentado nos textos, e não, em boxes explicativos.

Moreira e Martins (2015b) discutem que os livros didáticos representam uma possibilidade para organização do currículo; sendo os livros o reflexo de discursos impostos por políticas públicas, práticas de produção editorial e expressando uma decisão consensual, que na verdade não existe, pois refletem os poucos grupos editorais.

Os livros são similares em seus conteúdos e estrutura o que causa um fenômeno de convergência entre as coleções e abordagens da genética e seus conteúdos estruturantes. Igualmente exploram figuras, quadros e esquemas que resumem e reafirmam os conteúdos apresentados no texto corrido. Praticamente não se viu novidade nos esquemas e figuras, conferindo uma mesma tendência nas coleções. E nem é discutido a extensa nomenclatura da genética, esta é assumida como um conteúdo necessário, requerendo do estudante que este seja "alfabetizado em genética" (KNIPPELS, WAARLO e BOERSMA, 2005). Os livros permanecem com uma abordagem transmissiva, ao desfavorecerem a descoberta dos fenômenos. Quanto a interdisciplinaridade, esta fica a desejar, pois praticamente inexiste de forma eficaz, o que aparece são chamadas ou textos extras.

A linguagem usada é a mesma nas quatro coleções; se não forem problematizadas e contextualizadas, a Biologia passa a ser interpretada como uma área com muitos nomes exóticos. O estudante mesmo tendo contato com eles vai preferir o vocabulário do senso comum. $\mathrm{O}$ letramento científico passa pelo uso social da nomenclatura da área de estudo também, desta 
forma, estimular o uso do vocabulário faz parte do ensino e aprendizagem da Biologia. É uma ciência claramente com muitos termos específicos, mas não adianta evitá-los e sim, contextualizálos. Moreira e Martins (2015b) esclarecem que a linguagem presente nos livros didáticos está mudando de um discurso monológico e fechado, bem típico do discurso científico para um "em nome do diálogo constante com o estudante, num processo de elaboração conjunta do conhecimento" (p. 09). Porém, um dos objetivos dos livros didáticos é justamente inserir os estudantes na aprendizagem da linguagem científica.

Aos estudantes, é requerido um papel passivo e depositório de informações; desejando habilidades de memorização, ao invés do desenvolvimento de habilidades mais complexas, como problematização, análise, síntese e generalização (CAIMI, 2015).

Acerca dos exercícios disponíveis nas coleções, Silvério e Maestrelli (in DUSO e HOFFMANN, 2013) destacam que os professores assumem estes exercícios como referência para decidir o que ensinar e em que ordem fazê-lo; mesmo que sejam distantes da realidade de seus estudantes.

Realinhando a discussão para o Currículo Mínimo da SEEDUC-RJ, nenhuma coleção examinada agrupa citologia e genética no mesmo volume, isto causa um hiato pedagógico que pode atrapalhar o ensino de genética. A coleção 01 é a que mais se aproxima, pois embora os conteúdos estejam separados por séries escolares, não há o intervalo de um ano. Mesmo assim, os professores da SEEDUC-RJ se veem constantemente desafiados na abordagem dos conteúdos, haja vista que há avaliações externas que contemplam a citologia e a genética mendeliana no primeiro ano do ensino médio. O tempo de aula de Biologia é de 100 minutos no ensino regular, uma vez por semana, o que equivale a, aproximadamente, 80 horas anuais, e com, ao menos, seis avaliações bimestrais.

Para amenizar esta consternação, a SEEDUC-RJ publicou as atividades autorreguladas para cada série e bimestre, mas acabam sendo manuais disfarçados. A criatividade e a autonomia docente sempre são postas em xeque e, por conta da avaliação externa, o Sistema de Avaliação da Educação do Estado do Rio de Janeiro (SAERJ), os docentes abrem mão de suas metodologias. Porém, há um claro contrassenso, pois embora nenhuma coleção de livros didáticos aborde o Currículo Mínimo, todas as escolas da SEEDUC-RJ apresentam uma coleção selecionada. Logo, surge uma indagação: o que fazer? Cada professor decide se se preocupa com a avaliação externa, 
ou se acompanha o livro didático, ou ainda se faz o seu próprio currículo. São decisões complexas de serem tomadas; acredita-se que ocorra o hibridismo das três possibilidades e outras surgem. E decisões como a descrita acima, encarceram a Biologia como uma ciência claramente enciclopédica, e todas as coleções investigadas e o Currículo Mínimo cooperam para se manter assim.

Recentemente, o Ministério da Educação apresentou a proposta de discussões para uma Base Nacional Comum Curricular, reunindo em um portal o que cada Estado tem realizado em termos de currículo escolar (BRASIL, 2015). Convocando instituições, pesquisadores e os professores a participar desta construção. O objetivo é deixar claro o que cada estudante brasileiro deve ter acesso durante sua trajetória na educação básica, contudo ainda está em fase de elaboração e discussões.

\section{CONSIDERAÇÕES FINAIS}

Sugere-se que os livros didáticos incorporem os temas interligados, tais como citologia e genética mendeliana, mesmo sabendo que esse será um desafio para os autores de livros didáticos e para os professores. Os pesquisadores de didática em genética pedem estes conteúdos em uma mesma série escolar (AYUSO e BANET, 2002; KNIPPELS, WAARLO e BOERSMA, 2005). A coleção 01 se esforça para acompanhar este pedido.

O PNLEM tem sua importância por ser o único recurso oferecido de forma gratuita a educação pública nacional, logo sua exclusão, condenação e crítica não é a solução, necessita-se ofertar mais cursos de formação continuada e promover a heterogeneidade das editoras e dos autores e editores de livros didáticos. A intenção não é culpabilizar os livros didáticos, mas chamar a atenção em como este lida com a genética em conversa com a literatura pertinente ao ensino e aprendizagem da ciência da hereditariedade.

Acerca de cursos de formação continuada também se faz necessário ressignificar o que são para os docentes; a maioria dos professores não considera palestras como continuidade no desenvolvimento profissional, apenas quando são matriculados, ou em congressos, em encontros, e entre outros que geram uma certificação. Despertar para isso se faz urgente, pois com a internet é possível assistir palestras online e estas cooperarem para a formação. Outra situação é a 
acessibilidade, cada órgão gestor precisa ter uma política para liberação dos professores para tal finalidade.

A compartimentalização dos conteúdos em volumes é uma tendência das coleções examinadas, cabe, portanto, ao professor convocar os conteúdos supostamente já estudados para a abordagem da genética e estimular metodologias para promover o ensino e aprendizagem da hereditariedade. Os professores da educação básica precisam ser despertados como promotores de conhecimentos e não, apenas como executores dos currículos dos livros didáticos, pois muitos já fazem isto, mas não se reconhecem, e muito menos se valorizam neste papel.

As tendências que surgem, e elas surgem, precisam ser exequíveis em escolas reais, onde a maioria não dispõe de recursos e ambientes adequados. Enquanto que o uso dos aplicativos tecnológicos que emergem como uma novidade metodológica; a maioria dos jovens sabe lidar com elas e gostam dos desafios propostos, mas muitos professores ainda são resistentes ao uso da tecnologia na educação. Mudar esta concepção também é um desafio para melhorar a educação científica. Outra questão é a percepção de uma tendência em substituir as aulas práticas, experimentais por modelos didáticos, talvez por questões de biossegurança e por serem de baixo custo.

A pluralidade enriquece o espaço formativo, o que não foi visto nas coleções. Fomentar isto é um pedido antigo. Deve haver mudanças e diferenças e, não, convergências para que o professor da educação básica tenha opção ao selecionar uma coleção em detrimento à outra.

Contudo, é necessário repensar o currículo enciclopédico que a Biologia ainda tem. As políticas públicas para o ensino médio precisam se posicionar quanto ao conteúdo extenso desta área. A educação biológica é desejada na atualidade, mas no ensino médio não é pedido que o estudante se diplome em Biologia. Ou pior, que passe a estudar apenas para a aprovação, não levando o conhecimento biológico para além dos muros escolares.

A melhoria do ensino de Biologia está na união de várias frentes (didática, metodologia, formação continuada dos professores, recursos, entre outros), não será uma ação isolada que mudará esse cenário, mas fomentar a discussão e promover inquietações favorece mudanças metodológicas, e consequentemente, mudar o processo de aprendizagem. 


\section{REFERÊNCIAS}

AYUSO, G.E.; BANET, E. Alternativas a la enseñanza de la genética em educación secundaria. Enseñanza de las Ciencias. [s.I.], v. 20, n. 1, p. 133-157, 2002. Disponível em: <http://ddd.uab.cat/pub/edlc/02124521v20n1p133.pdf>. Acesso em: 14 de dez. de 2013.

BRASIL. Ministério da Educação (MEC), Secretaria de Educação Média e Tecnológica (Semtec). Parâmetros Curriculares Nacionais para o Ensino Médio: orientações educacionais complementares aos Parâmetros Curriculares Nacionais - Ciências da Natureza, Matemática e suas Tecnologias (PCN+). Brasília: MEC/Semtec, 2002. Disponível em: <http://portal.mec.gov.br/seb/arquivos/pdf/ciencian.pdf>. Acesso em: 21 de jun. de 2014.

. Ministério da Educação (MEC), Secretaria de Educação Básica. Orientações Curriculares para o Ensino Médio: Ciências da Natureza, Matemática e suas Tecnologias. Vol. 02. Brasília: MEC/SEB, 2006. Disponível em: <http://portal.mec.gov.br/seb/arquivos/pdf/book_volume_02_internet.pdf>. Acesso em: 16 de jun. de 2014.

Guia de livros didáticos: PNLD 2015: Biologia: ensino médio. Ministério da Educação, Secretaria de Educação Básica. Brasília, 2014. Disponível em: <http://www.fnde.gov.br/programas/livro-didatico/guias-do-pnld/item/5940guia-pnld-2015>. Acesso em: 26 de jul. de 2015.

Ministério da Educação (MEC). Base Nacional Comum Curricular. Portal. 2015. Disponível em: <http://basenacionalcomum.mec.gov.br/>. Acesso em: 02 de ago. de 2015.

CAIMI, F.E. As disciplinas escolares no contexto do PNLD: avanços, lacunas e desafios na avaliação do livro didático. Revista de Educação Pública. Cuiabá: MT. v. 24, n. 57, p. 525-543, 2015. Disponível em: <http://periodicoscientificos.ufmt.br/index.php/educacaopublica/article/view/783/pdf>. Acesso em: 03 de set. de 2015.

DUSO, L.; HOFFMANN, M.B. (Orgs). Docência em Ciências e Biologia: proposta para um continuado (re)iniciar. ljuí: Unijí, 2013.

FLÓRIA-SANTOS, M.; NASCIMENTO, L.C. Perspectivas histórias do Projeto Genoma e a evolução da enfermagem. Revista Brasileira de Enfermagem. v. 59, n. 03, p. 358-361, 2006. Disponível em: <http://www.scielosp.org/pdf/reben/v59n3/a20v59n3.pdf>. Acesso em: 19 de mai. de 2016.

GREENWOOD, S.A.; FONSECA, A.B. Espaços e caminhos da educação alimentar e nutricional no livro didático. Revista Ciência e Educação. Bauru, SP. v. 22, n. 01, p. 201-218, 2016. Disponível em: <http://www.scielo.br/pdf/ciedu/v22n1/1516-7313-ciedu-22-01-0201.pdf>. Acesso em: 10 de jun. de 2016.

KNIPPELS, M-C.P.J.; WAARLO, A.J.; BOERSMA, K.T. Design criteria for learning and teaching genetics. Journal of Biological Education. [s.I.]. 39(3), 2005. DOI: 10.1080/00219266.2005.9655976. Acesso em: 24 de jan. de 2014.

LEAL, C.A.; RÔÇAS, G.; BARBOSA, J.V. A genética compreendida por estudantes do fim da educação básica: avaliação de uma sequência didática em grupos sanguíneos. In: III Seminário Internacional de Educação em Ciências (SINTEC). Anais. Rio Grande, RS, p. 01-12. Disponível em: <http://www.casaleiria.com.br/sintec3/sintec3.htm>. Acesso em: 29 de nov. de 2014.

A genética na educação básica. In: X Encontro Nacional de Pesquisa em Educação em Ciências (X ENPEC). Anais. Águas de Lindóia, SP, p. 01-08, 2015. Disponível em: <http://www.xenpec.com.br/anais2015/lista_area_10.htm>. Acesso em: 01 de dez. de 2015.

MAYR, E. O desenvolvimento do pensamento biológico: diversidade, evolução e herança. Tradução: Ivo Martinazzo. Brasília, DF: Universidade de Brasília, 1998.

MOREIRA, M.C.A.; MARTINS, I.(a) A recontextualização de discursos da pesquisa em educação em ciências em livros didáticos de ciências: um estudo de caso. Revista Brasileira de Pesquisa em Educação em Ciências. v. 15, n. 02, p. 237-257, 2015. Disponível em: <http://revistas.if.usp.br/rbpec/article/view/697/425>. Acesso em: 10 de jun. de 2016. 
.(b) A influência da pesquisa acadêmica em livros didáticos de ciências: uma contribuição para o currículo de ciências. In: 37ạ Reunião Nacional da ANPED. Florianópolis, SC, p. 01-15, 2015. Disponível em: <http://37reuniao.anped.org.br/wp-content/uploads/2015/02/Trabalho-GT12-4163.pdf>. Acesso em: 10 de jun. de 2016.

NETO, J.M.; FRACALANZA, H. O livro didático de ciências: problemas e soluções. Revista Ciência \& Educação. Bauru, SP. v. 09, n. 02, p. 147-157, 2003. Disponível em: Acesso em: <http://www.scielo.br/pdf/ciedu/v9n2/01>. 11 de jun. de 2016.

RIO DE JANEIRO. Secretaria de Estado de Educação do Rio de Janeiro. Currículo Mínimo 2012 - Ciências e Biologia. 2012. Disponível em: <http://www.rj.gov.br/web/seeduc/exibeconteudo?article-id=759820>. Acesso em: 21 de jun. de 2014

Resolução SEEDUC no 4.866 de 14 de fev. de 2013. Disponível em: <http://download.rj.gov./documentos/10112/1459738/DLFE-58738.pdf/PUBLICACAORECURSOATRIO.PDF> Acesso em: 01 de julho de 2014.

SACRISTÁN, J.G. (Org) Saberes e incertezas sobre o currículo. Tradução: Alexandre Salvaterra. Porto Alegre: Penso, 2013. 


\section{ANEXO 1}

\section{COLEÇÕES DE BIOLOGIA DO PNLD - TRIÊNIO 2015-2017}

\begin{tabular}{|c|c|c|c|}
\hline № & Coleção & $\begin{array}{l}\text { Volume e os conteúdos } \\
\text { estruturantes }\end{array}$ & $\begin{array}{c}\text { Volume com o } \\
\text { conteúdo de genética }\end{array}$ \\
\hline 01 & $\begin{array}{l}\text { Bio } \\
\text { Sônia lopes e Sérgio Rosso } \\
\text { Editora Saraiva } \\
\text { São Paulo, 2aㅡ ed., } 2013\end{array}$ & $\begin{array}{l}\text { Volume 1: } \quad \text { Biologia celular, } \\
\text { citologia, núcleo, divisão celular }\end{array}$ & Volume 2: genética \\
\hline 02 & $\begin{array}{l}\text { Biologia } \\
\text { Vivian Lavander Mendonça } \\
\text { Editora AJS } \\
\text { São Paulo, 2a ed., } 2013\end{array}$ & $\begin{array}{l}\text { Volume 1: } \quad \text { Biologia } \\
\text { introdução à celular; } \\
\text { divisão celular }\end{array}$ & Volume 3: genética \\
\hline 03 & $\begin{array}{l}\text { Biologia } \\
\text { César da Silva Jr; Sezar Sasson e } \\
\text { Nelson Caldini Jr } \\
\text { São Paulo, Editora Saraiva } \\
11 \text { a ed., } 2013\end{array}$ & $\begin{array}{l}\text { Volume 1: ácidos nucleicos, } \\
\text { Biologia celular; citologia; o núcleo } \\
\text { celular; divisão celular }\end{array}$ & $\begin{array}{l}\text { Volume 3: metabolismo } \\
\text { celular; DNA; genética }\end{array}$ \\
\hline 04 & $\begin{array}{l}\text { Biologia em contexto } \\
\text { José Mariano Amabis e Gilberto } \\
\text { Rodrigues Martho } \\
\text { São Paulo, Editora Moderna } \\
\text { 1a ed., } 2013\end{array}$ & Volume 01: arquitetura das células & $\begin{array}{lr}\text { Volume } & 03: \\
\text { fundamentos } & \text { da } \\
\text { genética } & \end{array}$ \\
\hline 05 & $\begin{array}{l}\text { Biologia hoje } \\
\text { Sérgio Vasconcelos Linhares e } \\
\text { Fernando Gewandsznadjer } \\
\text { Rio de Janeiro, Editora Ática } \\
\text { 2a ed., } 2013\end{array}$ & Volume 01: célula & $\begin{array}{l}\text { Volume 03: genética: } 0 \\
\text { trabalho de Mendel }\end{array}$ \\
\hline 06 & $\begin{array}{l}\text { Biologia unidade e diversidade } \\
\text { José Arnaldo Favaretto } \\
\text { São Paulo, Editora Saraiva } \\
\text { 1a ed., } 2013\end{array}$ & $\begin{array}{l}\text { Volume 01: a célula; material } \\
\text { genético; núcleo celular; divisão } \\
\text { celular }\end{array}$ & $\begin{array}{l}\text { Volume 03: bases da } \\
\text { hereditariedade }\end{array}$ \\
\hline 07 & $\begin{array}{l}\text { Conexões com a Biologia } \\
\text { Rita Helena Bröckelmann } \\
\text { São Paulo, Editora Moderna } \\
\text { 1a ed., } 2013\end{array}$ & $\begin{array}{l}\text { Volume 01: a célula; núcleo; } \\
\text { divisão celular; o material genético } \\
\text { das células; } \quad \text { cromossomos } \\
\text { eucariontes; ciclo celular; mitose; } \\
\text { meiose }\end{array}$ & $\begin{array}{l}\text { Volume 03: genética e } \\
\text { herança }\end{array}$ \\
\hline 08 & $\begin{array}{l}\text { Novas bases da Biologia } \\
\text { Nélio M. Vicenzo Bizzo } \\
\text { Rio de Janeiro, Editora Ática } \\
\text { 2a ed., } 2013\end{array}$ & $\begin{array}{l}\text { Volume 01: as bases da vida; } \\
\text { organismo vivo }\end{array}$ & Volume 3: genética \\
\hline 09 & $\begin{array}{l}\text { Ser protagonista - Biologia } \\
\text { Marcia Takeuchi e Tereza Osorio } \\
\text { Rio de Janeiro, Editora SM } \\
\text { 2a ed., } 2013\end{array}$ & $\begin{array}{l}\text { Volume 01: citologia: introdução à } \\
\text { citologia; o núcleo celular; divisão } \\
\text { celular }\end{array}$ & $\begin{array}{l}\text { Volume 03: genética; } \\
\text { Gregor Mende e a } \\
\text { genética }\end{array}$ \\
\hline
\end{tabular}




\section{ANEXO 2}

\section{COLEÇÕES DE BIOLOGIA DO PNLD - TRIÊNIO 2015-2017}

\begin{tabular}{|c|c|c|c|c|}
\hline № & $\begin{array}{l}\text { Nome da } \\
\text { coleção }\end{array}$ & Identificação & № de páginas & Principais temas abordados \\
\hline \multirow{3}{*}{01} & \multirow{3}{*}{$\mathrm{BIO}$} & \multirow{3}{*}{$\begin{array}{l}\text { Sônia Lopes e Sérgio } \\
\text { Rosso. } \quad \text { Editora } \\
\text { Saraiva; 2a } \\
\text { São Pauloção. } 2013\end{array}$} & $\begin{array}{l}\text { Vol. } 01: 320 \\
\text { Com manual do professor: } \\
448\end{array}$ & $\begin{array}{l}\text { Introdução à ecologia; e } \\
\text { origem da vida e Biologia } \\
\text { celular }\end{array}$ \\
\hline & & & $\begin{array}{l}\text { Vol. 02: } 320 \\
\text { Com manual do professor: } \\
432\end{array}$ & $\begin{array}{l}\text { Espécie humana; genética; e } \\
\text { evolução }\end{array}$ \\
\hline & & & $\begin{array}{l}\text { Vol. 03: } 320 \\
\text { Com manual do professor: } \\
448\end{array}$ & $\begin{array}{l}\text { Sistemática; vírus; e reinos } \\
\text { dos seres vivos }\end{array}$ \\
\hline \multirow{3}{*}{02} & \multirow{3}{*}{ Biologia Hoje } & \multirow{3}{*}{$\begin{array}{l}\text { Sérgio Linhares e } \\
\text { Fernando } \\
\text { Gewandsznajder. } \\
\text { Editora Ática; 2ạ } \\
\text { edição. São Paulo, } \\
2013\end{array}$} & $\begin{array}{l}\text { Vol. 01: } 312 \\
\text { Com manual do professor: } \\
400\end{array}$ & $\begin{array}{l}\text { Citologia; reprodução e } \\
\text { desenvolvimento; histologia; } \\
\text { e origem da vida }\end{array}$ \\
\hline & & & $\begin{array}{l}\text { Vol. } 02: 320 \\
\text { Com manual do professor: } \\
408\end{array}$ & $\begin{array}{l}\text { Os seres vivos; e anatomia e } \\
\text { fisiologia humanas }\end{array}$ \\
\hline & & & $\begin{array}{l}\text { Vol. 03: } 312 \\
\text { Com manual do professor: } \\
408\end{array}$ & $\begin{array}{l}\text { Genética; evolução; } \\
\text { ecologia }\end{array}$ \\
\hline \multirow{3}{*}{03} & \multirow{3}{*}{$\begin{array}{l}\text { Conexões com } \\
\text { a Biologia }\end{array}$} & \multirow{3}{*}{$\begin{array}{l}\text { Rita Helena } \\
\text { Bröckelmann. } \\
\text { Editora Moderna; 1a } \\
\text { edição. São Paulo, } \\
2013\end{array}$} & $\begin{array}{l}\text { Vol. 01: } 248 \\
\text { Com manual do professor: } \\
382\end{array}$ & $\begin{array}{l}\text { Citologia; histologia animal; } \\
\text { e reprodução } \\
\text { desenvolvimento }\end{array}$ \\
\hline & & & $\begin{array}{l}\text { Vol. 02: } 312 \\
\text { Com manual do professor: } \\
432\end{array}$ & $\begin{array}{l}\text { Classificação e diversidade; e } \\
\text { reinos dos seres vivos; }\end{array}$ \\
\hline & & & $\begin{array}{l}\text { Vol.03: } 302 \\
\text { Com manual do professor: } \\
431\end{array}$ & $\begin{array}{l}\text { Genética e herança; } \\
\text { evolução; e ecologia }\end{array}$ \\
\hline \multirow{3}{*}{04} & \multirow{3}{*}{$\begin{array}{l}\text { Ser } \\
\text { protagonista }\end{array}$} & \multirow{3}{*}{$\begin{array}{l}\text { Márcia Regina } \\
\text { Takeuchi e Tereza } \\
\text { Costa Osorio. Editora } \\
\text { SM; 2a edição. São } \\
\text { Paulo, 2013 }\end{array}$} & $\begin{array}{l}\text { Vol. } 01: 320 \\
\text { Com manual do professor: } \\
432\end{array}$ & $\begin{array}{lr}\text { Citologia; Biologia } & \text { do } \\
\text { desenvolvimento; } & \text { e } \\
\text { histologia animal } & \\
\end{array}$ \\
\hline & & & $\begin{array}{l}\text { Vol. } 02: 320 \\
\text { Com manual do professor: } \\
432\end{array}$ & $\begin{array}{l}\text { Sistemática e classificação } \\
\text { dos seres vivos; vírus; reinos } \\
\text { dos seres vivos; e fisiologia e } \\
\text { sistemas de órgãos humanos }\end{array}$ \\
\hline & & & $\begin{array}{l}\text { Vol. 03: } 311 \\
\text { Com manual do professor: } \\
408\end{array}$ & $\begin{array}{l}\text { Genética; } \\
\text { ecologia }\end{array}$ \\
\hline
\end{tabular}

